\title{
Correlation between Microstructure and Mechanical Properties of Austempered Ductile Irons
}

\section{Vinícius Cardilo Campos Alves ${ }^{1, a^{*}}$, Luciano Lobo De Almeida Baracho ${ }^{1, b}$, Césio Túlio Alves Dos Santos ${ }^{1, \mathrm{c}}$, Luiz Carlos Rolim Lopes ${ }^{1, d}$, Éder Dos Reis Silva ${ }^{2, e}$, Fabiane Roberta Freitas Da Silva ${ }^{1, f}$, Gláucio Soares Da Fonseca ${ }^{1,9}$, Ricardo Henriques Leal ${ }^{1, \mathrm{~h}}$, Maria Da Penha Cindra Fonseca,}

\author{
${ }^{1}$ Avenida dos trabalhadores, 420, Vila Santa Cecília, Volta Redonda, RJ, Brasil \\ ${ }^{2}$ Rua Dr. João Colin, 2700, Santo Antônio, Joinville, SC, Brasil \\ ${ }^{3}$ Rua Passo da Pátria, 156, São Domingos, Niterói, RJ, Brasil \\ aviniciuscardilo@id.uff.br, bluklobo@gmail.com, cesiosantos@id.uff.br, duiz.crolim@uol.com, \\ ereis.eder@outlook.com, fabianesilva@id.uff.br, ${ }^{9}$ glaucio@metal.eeimvr.uff.br, ${ }^{\text {h}}$ rhleal@id.uff.br, \\ imcindra@vm.uff.br
}

Keywords: Austempered ductile cast iron, residual austenite, tensile strength, residual stress, impact strength

\begin{abstract}
Austempered ductile cast irons (ADI) have received great attention in last years because their combined properties of good ductility, high strength and fracture toughness, good fatigue strength, good wear properties and low production cost. Such combination of properties can be reached because of their microstructures consist of a mixture acicular ferrite (bainite), residual austenite with a high carbon content and nodular graphite. In this work, the effect of austempering heat treatment on the microstructure of a commercial alloy to produce three different grades of ADI, with different strength level, is analyzed. Microstructure characterization has been performed using techniques of optical microscopy, scanning electron microscopy and x-ray diffraction. Mechanical properties were evaluated from tensile and impact tests at room temperature. In addition, the residual stress due to heat treatment was evaluated. The results of this study show that there is a strong relationship between austempering temperatures and mechanical properties. The highest tensile and yield strength obtained were 1599 and $1427 \mathrm{MPa}$, respectively, for the sample austempered at $280^{\circ} \mathrm{C}$. The sample austempered at $320^{\circ} \mathrm{C}$ presented the highest Charpy absorption energy $(99,90 \mathrm{~J})$ and highest volume fraction of austenite $(27 \%)$.
\end{abstract}

\section{Introduction}

The as-cast mechanical properties of ductile iron can be significantly improved through an austempering heat treatment. This has led to a new grade of cast irons, the austempered ductile iron (ADI), with its unique microstructure composed by an ausferritic matrix with spheroidal graphite [1]. ADI has emerged as an important engineering material in recent years because of the combination of properties such as high strength, good ductility, good wear resistance, high fatigue strength and fracture toughness [2]. Furthermore, ADI is also 10\% less dense than steel [3], producing high specific strength when compared to other classes of materials [4]. Because of these advantages, allied with low production costs, ADI has been commonly used in many commercial engineering applications, such as in automotive components [5].

The production of ADI consists in the casting of ductile iron, followed by a heat treatment that begins with heating above the transformation temperature range, maintained long enough to create a fully austenitic matrix $(\gamma)$ saturated with carbon. Then, the iron is suddenly cooled to a temperature in the bainitic range $\left(260-400^{\circ} \mathrm{C}\right)$. At this temperature, if the iron is held for the required amount of time, the austempering reaction takes place. During austempering, part of austenite decomposes 
into acicular ferrite $(\alpha \mathrm{B})$ while the remaining austenite is enriched with carbon $\left(\gamma_{\mathrm{HC}}\right)[6]$. This reaction is often represented [7] by Eq. 1:

$$
\gamma \rightarrow \alpha \mathrm{B}+\gamma_{\mathrm{HC}}
$$

On the other hand, if the austempering temperature is held for too long a second reaction occurs and must be avoided. During this reaction, the high carbon austenite $\left(\gamma_{\mathrm{HC}}\right)$ is decomposed into ferrite $(\alpha)$ and carbide $(\varepsilon)$, causing the embrittlement of the material [8]. Eq. 2 represents this reaction:

$$
\gamma_{\mathrm{HC}} \rightarrow \alpha+\varepsilon \text {. }
$$

Therefore, the desired properties and microstructure of ADI are achieved after the completion of the first stage reaction but before the second stage reaction takes place.

The austempering time and temperature determine the final microstructure and properties of ADI. At lower temperatures, it has high yield strength and hardness, due to the presence of a very thin ferrite and austenite. At higher austempering temperatures, the ferrite becomes coarser with increased volume fraction of retained austenite, resulting in a significantly increase in ductility with lower values of yield strength $[9,10,11]$.

\section{Experimental Procedure}

Materials. The chemical composition of ductile iron used in this study is presented in Table 1 . The material was originally cast in circular cross section bars. From these bars, samples for tension and impact tests were taken.

Table 1 - Chemical composition of ductile cast iron.

\begin{tabular}{cccccccccc}
\hline \multicolumn{10}{c}{ Composition [\% wt] } \\
\hline $\mathrm{C}$ & $\mathrm{Si}$ & $\mathrm{Cu}$ & $\mathrm{Ni}$ & $\mathrm{Mo}$ & $\mathrm{Mn}$ & $\mathrm{Cr}$ & $\mathrm{Mg}$ & $\mathrm{P}$ & $\mathrm{S}$ \\
\hline 3,4 & 3,1 & 0,666 & 0,616 & 0,293 & 0,2 & 0,06 & 0,042 & 0,1 & 0,009
\end{tabular}

Heat treatment. After machining, the samples were subjected to three distinct heat treatments. One group was austenitized at $910^{\circ} \mathrm{C}$ for $60 \mathrm{~min}$ and austempered at $320^{\circ} \mathrm{C}$ for $90 \mathrm{~min}$; the second and the third groups were both austenitized at $930^{\circ} \mathrm{C}$ for $120 \mathrm{~min}$ and then austempered for $40 \mathrm{~min}$ at $300^{\circ} \mathrm{C}$ and $280^{\circ} \mathrm{C}$ respectively.

Microstructural analysis. Metallographic samples were taken from each of the heat-treated condition, including the as cast alloy. These samples were prepared in accordance with standard procedures for optical and SEM analysis.

$\mathrm{X}$-ray diffraction analyses were performed to measure $\gamma$ volume fraction and its carbon content. It was done using a monochromatic $\mathrm{Cu}-\mathrm{K} \alpha$, scanning the angular $2 \theta$ range from $40^{\circ}$ to $50^{\circ}$, with an angular speed of $0,25^{\circ} / \mathrm{min}$ and an angular step of $0,02^{\circ}$. The profiles were then analyzed using the software PowderCell. The carbon content of the austenite was determined by Eq. 3 [12]:

$$
\text { a } \gamma=0,3548+0,00441 C \gamma \text {. }
$$

where a $\gamma$ is the lattice parameter of austenite (in $\mathrm{nm}$ ) and $\mathrm{C} \gamma$ is the carbon content of austenite (in wt $\%$ ).

Residual stress. The residual stress measurements were performed and evaluated by the X-ray diffraction technique using the method of $\operatorname{sen}^{2} \Psi$. The Xstress3000 analyazer was used, with a monochromatic $\mathrm{Cr}-\mathrm{K} \alpha$ radiaton, at five different angles of $\psi\left(0^{\circ} ; 20,7^{\circ} ; 30^{\circ} ; 37,8^{\circ} ; 45^{\circ}\right)$ with an exposure time of 5 seconds.

Mechanical testing. Tensile and Charpy impact toughness tests were performed at room temperature with unnotched specimens and Brinell hardness was measured. For the tensile testing, three samples were tested in each heat-treated condition, with a constant engineering strain rate of $0,2 \mathrm{~mm} / \mathrm{min}$. Five specimens were used for each heat-treated condition in Charpy impact tests. 


\section{Results and Discussion}

Fig. 1 presents the SEM micrographs of the studied alloy. In the as-cast sample (Fig. 1a), the micrograph shows a structure containing dispersed graphite nodules in a matrix of $50 \%$ ferrite and $50 \%$ pearlite. A characteristic ferrite layer is observed around the graphite nodules, commonly called bull's eye.

The microstructure of the austempered samples (Fig. 1b-d) also contains dispersed graphite nodules. However, the matrix is composed of acicular ferrite and austenite, also known as ausferrite. The acicular ferrite is presented as needles, while the austenite is the phase between. These micrographs also show the influence of austempering temperature on the resulting microstructure. At $320^{\circ} \mathrm{C}$, the microstructure appears coarser with larger interconnected areas of austenite, while at $280^{\circ} \mathrm{C}$ the microstructure is finner with less retained austenite. No carbide formation was observed in all samples, through x-ray diffraction and SEM techniques, therefore it is assumed, for this chemical composition, that 40 and 90 minutes of austempering fit the processing window.

The volume fraction of austenite and austenitic carbon is presented in Table 2 as a function of austempering temperature. The sample austempered at $320^{\circ} \mathrm{C}$ presented approximately $41 \%$ more retained austenite than the other samples. This difference is because it's heat treatment promotes greater carbon enrichment in austenite due to higher austempering time.
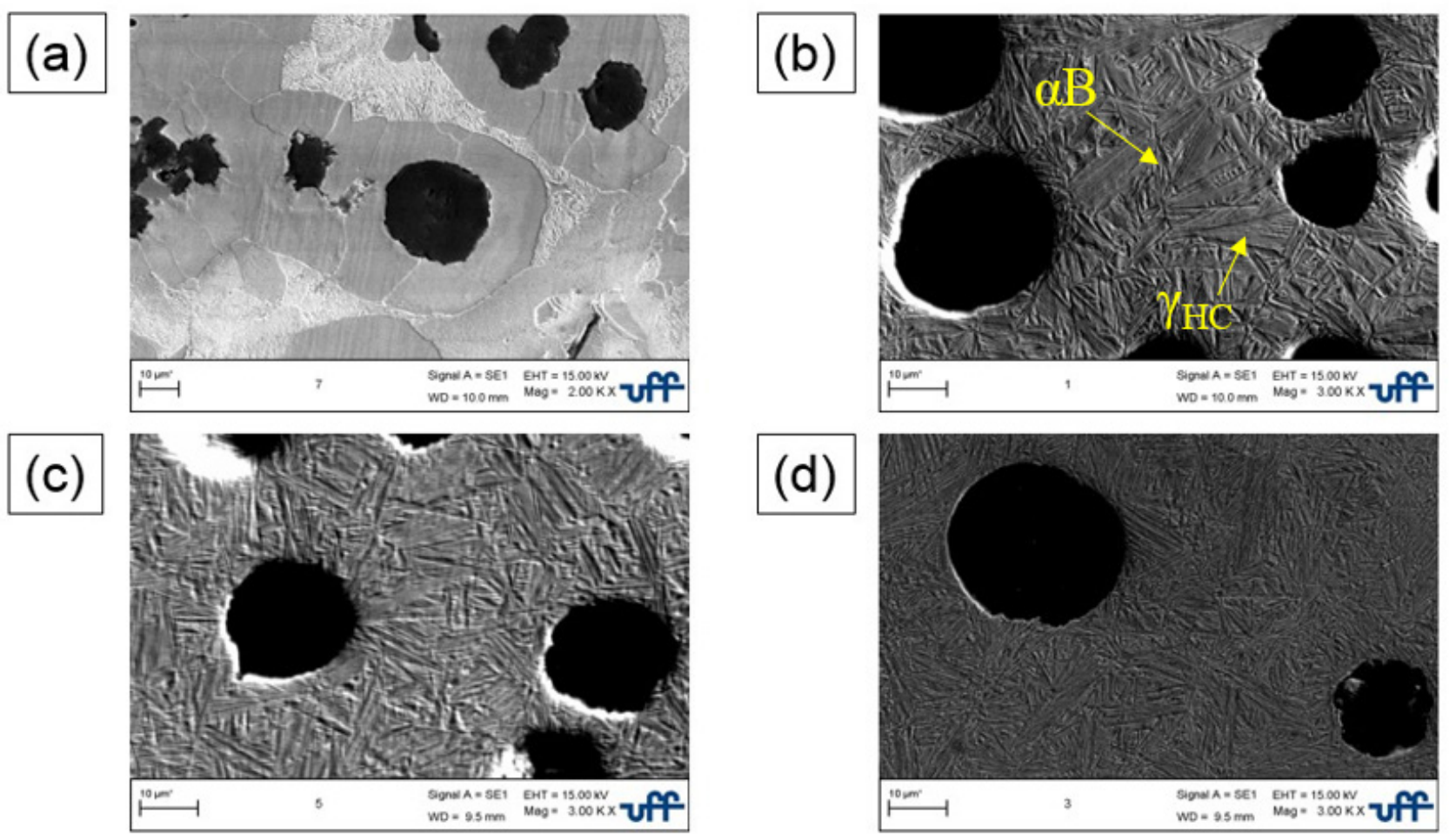

Fig. 1 - SEM micrographs of ductile iron in (a) as-cast condition and austempered at (b) $320^{\circ} \mathrm{C}$, (c) $300^{\circ} \mathrm{C}$ and (d) $280^{\circ} \mathrm{C}$.

The austenitic carbon is a function of volume fraction of austenite and its carbon content. It expresses the rate of austenite enrichment during carbon partitioning. As the austempering temperature and time increases, the volume fraction of austenitic carbon also tends to increases [9]. 
Table 2 - Volume fraction of austenite and austenitic carbon.

\begin{tabular}{c|ccc}
\hline $\begin{array}{c}\text { Austempering } \\
\text { temperature }\left[{ }^{\circ} \mathbf{C}\right]\end{array}$ & $\begin{array}{c}\text { Volume fraction of } \\
\text { austenite } \mathbf{V} \boldsymbol{\gamma}[\%]\end{array}$ & $\begin{array}{c}\text { Austenite carbon } \\
\text { content } \mathbf{C} \boldsymbol{\gamma}[\mathbf{w t} \%]\end{array}$ & $\begin{array}{c}\text { Volume fraction of } \\
\text { austenitic carbon } \\
{[\mathbf{V} \boldsymbol{\gamma} \mathbf{C} \boldsymbol{}]}\end{array}$ \\
\hline $\mathbf{3 2 0}$ & 27,30 & 1,63 & 0,44 \\
\hline $\mathbf{3 0 0}$ & 19,40 & 1,88 & 0,36 \\
\hline $\mathbf{2 8 0}$ & 15,60 & 1,73 & 0,27 \\
\hline
\end{tabular}

For the specimens austempered at $280^{\circ} \mathrm{C}$, a lower volume fraction of austenite with high carbon content can be observed. The lower the volume fraction of austenite, the higher should be it's carbon content for the same heat treatment conditions. The sample austempered at $300^{\circ} \mathrm{C}$ presented a slightly increased volume fraction of austenite, when compared to the sample austempered at $280^{\circ} \mathrm{C}$, with a higher carbon content. This can be explained by the increase in austempering temperature, which promotes diffusional process during carbon partitioning. As the residual austenite becomes coarser, longer austempering time is required to attain the same value of carbon content, as can be seen in the sample austempered at $320^{\circ} \mathrm{C}$, which presented the highest volume fraction of austenite and the lowest carbon content.

The mechanical properties are presented in Table 3. All three austempering treatments have produced ADI alloys with higher tensile properties than the as-cast condition, but with lower elongation.

Fig. 2 shows that tensile and yield strengths decrease with volume fraction of austenite, while elongation increases.

Brinell hardness increased significantly from the as-cast condition to the austempered samples; moreover, hardness presents a decrease with austempering temperature. As the microstructure becomes coarser at higher austempering temperatures, hardness tends to decrease.

Impact energy also improves with austempering temperature. For austempered samples, brittleness increased as the volume fraction of austenite decreases. A direct relationship between impact energy and austenite volume fraction can be observed in Fig 3.

Table 3 - Mechanical properties of ADI.

\begin{tabular}{c|ccccc}
\hline $\begin{array}{c}\text { Austempering } \\
\text { temperature } \\
{\left[{ }^{\circ} \mathbf{C}\right]}\end{array}$ & $\begin{array}{c}\text { Yield } \\
\text { strength } \\
{[\mathbf{M P a}]}\end{array}$ & $\begin{array}{c}\text { UTS } \\
{[\mathbf{M P a}]}\end{array}$ & $\begin{array}{c}\text { Elongation } \\
{[\%]}\end{array}$ & $\begin{array}{c}\text { Brinnel } \\
\text { hardness }\end{array}$ & $\begin{array}{c}\text { Impact } \\
\text { energy [J] }\end{array}$ \\
\hline As-cast & $673 \pm 146$ & $870 \pm 123$ & $7,24 \pm 4,65$ & 255 & 45,00 \\
\hline $\mathbf{3 2 0}$ & $1242 \pm 102$ & $1433 \pm 58$ & $3,52 \pm 2,62$ & 370 & $99,90 \pm 17,48$ \\
\hline $\mathbf{3 0 0}$ & $1292 \pm 44$ & $\begin{array}{c}1495 \pm \\
218\end{array}$ & $3,43 \pm 2,56$ & 395 & $76,17 \pm 21,87$ \\
& & & & \\
\hline $\mathbf{2 8 0}$ & $1427 \pm 133$ & $\begin{array}{c}1599 \pm \\
238\end{array}$ & $3,12 \pm 2,73$ & 445 & $67,92 \pm 20,94$ \\
& & & & \\
\hline
\end{tabular}




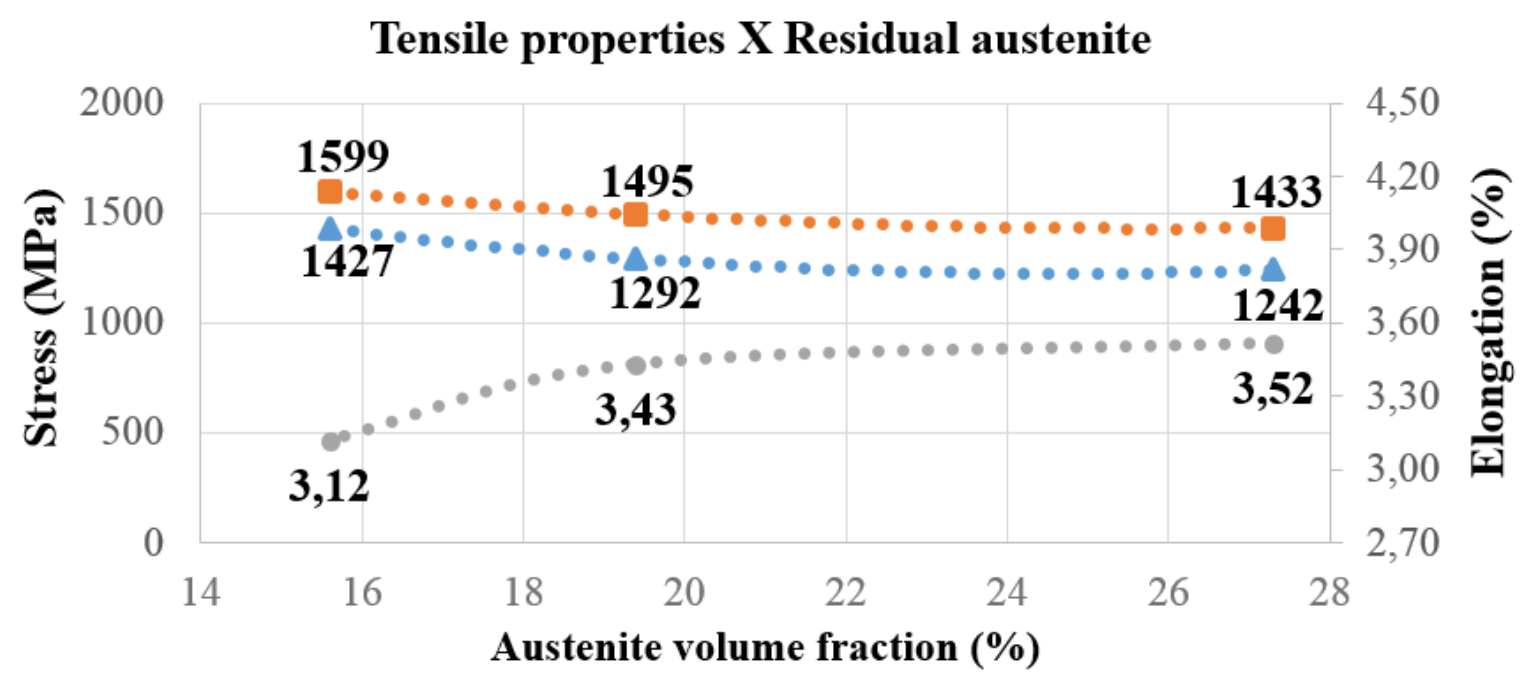

$\Delta$ Yield Strength Ultimate Tensile Strength $\bullet$ Elongation

Fig. 2 - Relationship between tensile properties and residual austenite.

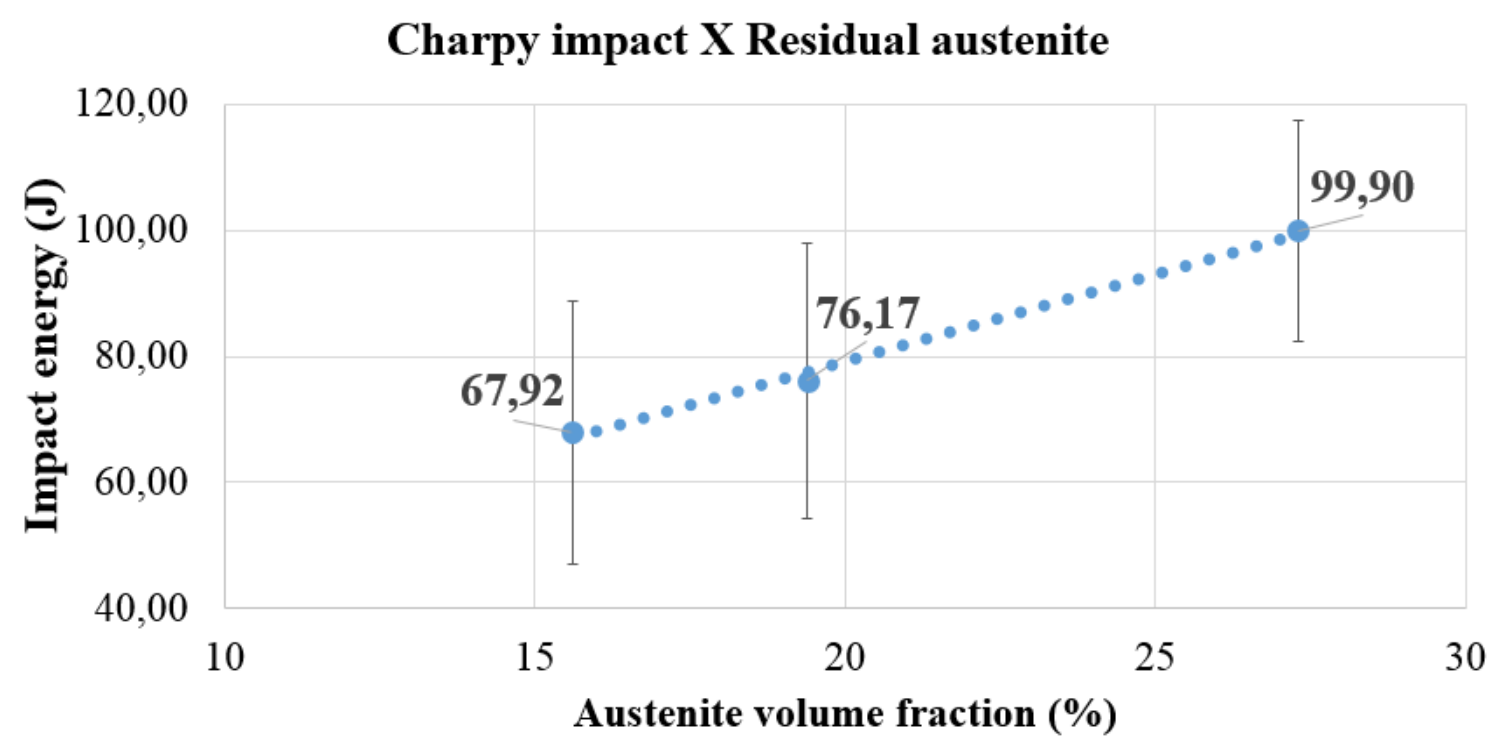

Fig. 3 - Relationship between impact energy and retained austenite.

This relationship between austempering temperature and strengthening effects is in agreement with previous results $[9,10,13]$. At higher austempering temperature, upper ausferritic transformation takes places. In this range, ADIs can achieve enhanced ductility but smaller increase in strength and hardness result in comparison to those ADI's that have transformed at lower ausferrite temperature ranges.

The relationship between residual stress and austempering temperature is shown in Fig.4. It was found in all samples a state of tensile stresses in the acicular ferrite, due to its phase transformation during heat treatment. The carbon saturation in acicular ferrite promotes a distortion in crystalline lattice, which is interpreted as tensile stress, as the residual stress is directly related with lattice plane spacing d, according to Bragg's law [14]. For higher austempering temperature, carbon diffusion from acicular ferrite to residual austenite occurs rapidly, relieving the stress generated in interstitial solid solution. 


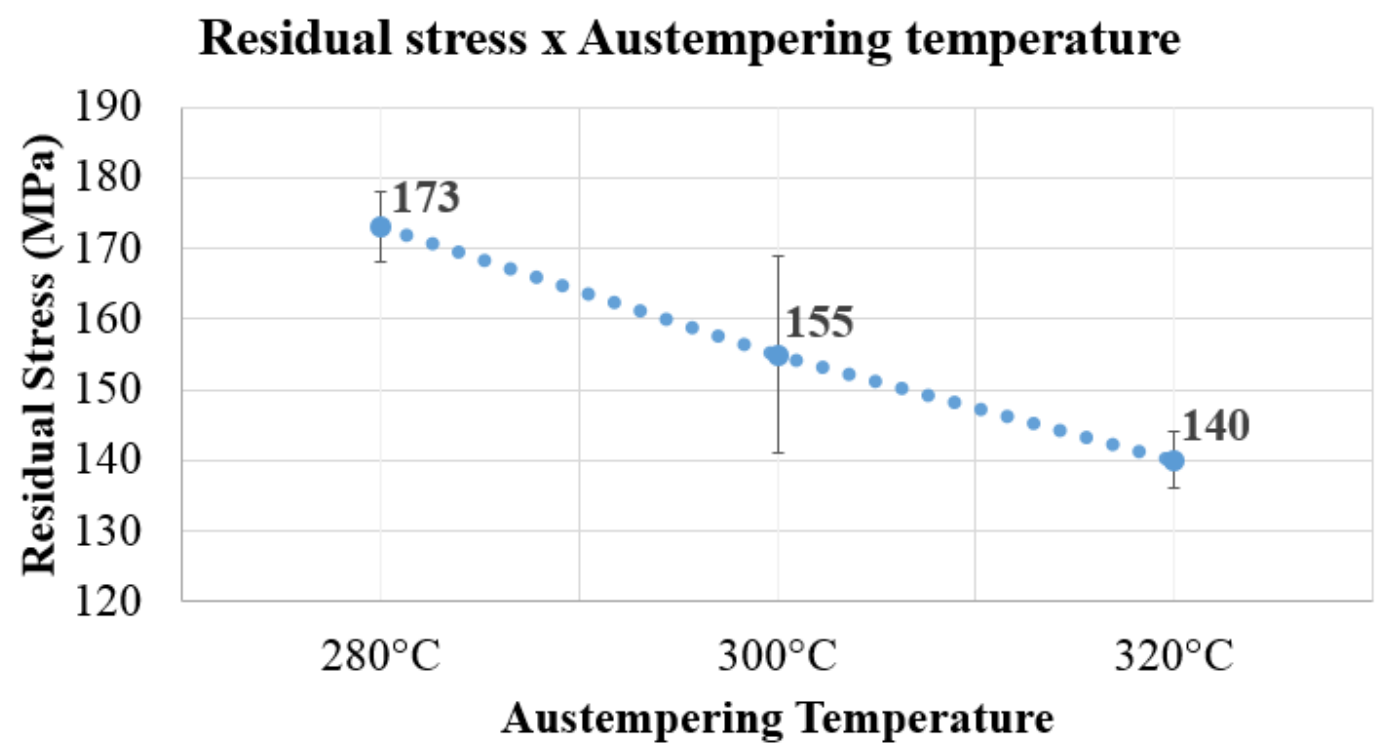

Fig. 4 - Correlation between residual stress and austempering temperature.

\section{Conclusions}

The effect of three different austempering heat treatments on the mechanical properties of ADI has been studied. The following conclusions can be drawn:

1. There is a clear correlation between austempering temperatures and mechanical properties. The samples treated at lower austempering temperatures presented high tensile strength and hardness. High austempering temperatures lead to higher volumes of residual austenite, with enhanced ductility.

2. Austenite stability at room temperature is mostly defined by carbon enrichment during austempering reaction. Higher austenitization times showed no great influence on samples austempered for $40 \mathrm{~min}$ when compared with the sample with an austenitization of $1 \mathrm{~h}$ and austempered for $90 \mathrm{~min}$.

3. The residual stress in acicular ferrite is inversely proportional to austempering temperature, as the tensile stress observed, is basically related to carbon retained in instertitial solid soution.

\section{Acknowledgments}

Two authors, Baracho and Alves, are greatfull to CAPES for the financial support to this work through master fellowships, to PROPPi/UFF for supporting the PPGEM/EEIMVR/UFF and to Tupy's foundry for the alloy samples.

\section{References}

[1] R.A. Harding, The production, properties and automotive applications for austempered ductile iron, Kovove Mater. 45 (2007) 1-16.

[2] ASM Handbook Volume 1, Properties and Selection: Irons, Steels and High Performance Alloys, tenth ed., ASM International, 2005.

[3] R.C. Voigt, Austempered ductile iron-processing and properties, Int. J. Cast Metal Res. 2 (1989), 72-93.

[4] J.R. Keough, K.L. Hayrynen, Automotive applications of austempered ductile iron (ADI): a critical review, 2000 SAE World Congress: Technical Paper (2000) 1-12.

[5] J. Panasiewicz, C. Grupke, J. Huth, Chrysler's experience with austempered ductile iron, in: Proceedings of the World Conference on Austempered Ductile Iron (1991) 323-336.

[6] B.V. Kovacs, Austempered ductile iron facts and fiction, Mod. Cast. 36 (1990) 38-41.

[7] A. Nofal, Advances in the metallurgy and applications of ADI, J. Metal. Eng. 2 (2013) 1-18. 
[8] R.A. Harding, Control of the retained austenite content of ADI, AFS Int. Cast Met. J. 1 (1991) 22-31.

[9] S. Panneerselvam, C.J. Martins, S.K. Putatunda, J.M. Boileau, An investigation on the stability of austenite in austempered ductile iron, Mat. Sci. Eng. A-Struct. 626 (2015) 237-246.

[10] Y.J. Kim, H. Shin, H. Park, J.D. Lim, Investigation into mechanical properties of austempered ductile cast iron (ADI) in accordance with austempering temperature, Mater. Lett. 62 (2008) 357360.

[11] Cast Metals Development Ltd., Austempered ductile-iron castings - advantages, production, properties and specifications, Mater. Design 13 (1992) 285-297.

[12] C.S. Roberts, Effect of carbon on the lattice parameter of austenite, T. Am. I. Min. Met. Eng. (1982) 203-204.

[13] S.K. Putatunda, S. Kesani, R. Tackett, G. Lawes, Development of austenite free ADI (austempered ductile iron), Mat. Sci. Eng. A-Struct. 435 (2006) 112-122.

[14] P.J. Withers, Residual stress and its role in failure, Rep. Prog. Phys. 70 (2007) 2211-2264. 